\title{
FORESTRY EDUCATION IN BRITISH COLUMBIA
}

\author{
By J. E. LIERSCH
}

Department of Forestry, University of British Columbia, Vancouver, B.C.

$\mathrm{T}$

HE DEPARTMENT of Forestry was established in the Faculty of Applied Science at the University of British Columbia in 1921. The course offered at that time was a combination of forestry and civil engineering designed to meet the demand of the logging industry for trained logging engineers, and of the Provincial Forest Service for technically trained foresters.

This same course with relatively minor changes was offered until the year 1937. Then, due to an increasing demand from industry for men specially trained in business, and by students who wished to take forestry but felt they were not suited to the rigorous engineering training offered by the forest engineering course, the curriculum was expanded to allow four options leading to a degree in forestry. The forest engineering course remained unchanged and options were set up which allowed a student to take four years in the departments of either Botany, Economics or Commerce in the Faculty of Arts and Science, and a fifth year in the Faculty of Applied Science, taking only forestry subjects. In the last three options the students were granted their B.A. at the end of four years and their B.S.F. at the end of the fifth. In forest engineering the B.A.Sc. degree was granted on completion of 5 years.

The latter courses were offered from 1937 to 1945 , when a complete change was made in the forestry courses leading to the B.S.F. degree. These changes were necessitated because, while the theory behind the original adoption of the options was sound, in practice it was found that it was impossible to crowd enough forestry into a year of instruction to warrant the granting of a forestry degree. It was found, too, that the basic foundation on which forestry was superimposed was too varied and inadequate.

\section{Courses Offered at Present}

The new courses were offered for the first time this year and it is felt that they are a great improvement on the old. One of the principal considerations stressed is the requirement that all forestry graduates, no matter which option is elected, will have very nearly the same training in the basic sciences so important to forestry.

In the following description of courses offered the B.S.F. options will be discussed first, and the forest engineering course discussed later. 
B. S. F.

There are three separate courses offered leading to the degree of B.S.F. All these courses require five years following Junior Matriculation, or four years following Senior Matriculation. Upon entering the University the student is required to register for the first year in the Faculty of Arts and Science, and must take biology, chemistry, mathematics, English and a foreign language. In order to qualify for the first year in the Faculty of Applied Science he must make at least 60 per cent in biology, chemistry and mathematics, and 50 per cent in English and the foreign language.

The first year in Applied Science is common to all three options leading to the B.S.F. degree and consists of the following subjects:-

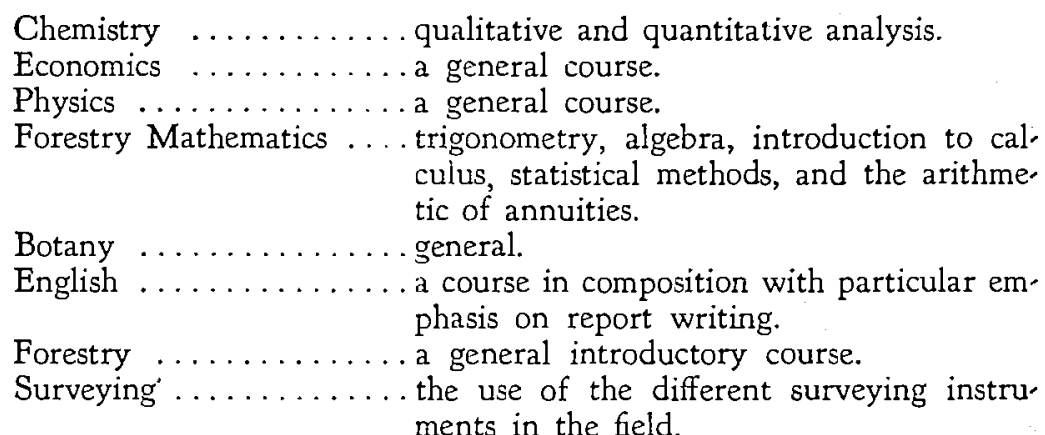

The above course is fairly heavy, being equivalent to 20 units under our system as compared to 15 required in the first year. (one unit consists of one hour lecture per week throughout the year, or 3 hours laboratory work per week throughout the year).

The second year in Applied Science is also common to the 3 options offered, and the subjects are as follows:-

Plant Physiology

Dendrology

Silvics ............. Factors affecting growth, development and distribution of trees.

Forest Surveying

and Mapping ......... Particular attention paid to forest-type mapping, topographic mapping, and cruising.

Wood Technology ..... The structure of wood and its microscopic identification.

Forest Fire Protection.

One of the following:-

Zoology .............. general course.

Systematic Botany ......

Organic Chemistry ......

Geology .............. general course. 
The above course consists of 17 units and in addition to a continuation of the study of the basic sciences (more particularly botany) there is a considerable amount of introductory forestry work.

During the last two years in college students are required to elect one of the following three options:-
A Technical Forestry
B Chemical Wood Products
C Forest Business Administration'

The technical forestry option is designed primarily to train men in silviculture, mensuration and forest management; in which they receive extra instruction beyond the basic courses offered in these subjects to all students. These students will be primarily fitted for government work and research activities, with a small percentage going to private industries which have set up their own forestry departments. Their third year consists of courses in:-

\author{
Silviculture \\ Forest Mensuration \\ Forest History \\ Forest Management \\ Forest Pathology \\ Forest Entomology \\ Seminar \\ The final year in this option is as follows:-
Âdvanced Silviculture
Advanced Mensuration
General Logging
Lumber Grading
Forest Economics
Advanced Management
Milling and Marketing
Forest Products
Forest Ecology
Seminar

Wood Technology ..... the microscopic structure and identification

Total 16 Units

Total 20 Units

The chemical wood products option was initiated this year to supply an increasing demand for trained men in this fast expanding field. In this course the student is required to take all but two of the undergraduate chemistry courses offered by the university, in addition to the basic forestry courses. We are very careful to stress to students, however, that this course does not qualify them as wood chemists, but only lays a sound foundation on which to continue past-graduate work in this highly specialized field. Their third year consists of the following subjects:- 


\title{
FORESTRY CHRONICLE
}

\author{
Silviculture \\ Forest Mensuration \\ Wood Technology \\ Forest Management \\ Forest Pathology \\ Forest Entomology \\ Theoretical Chemistry \\ Seminar
}

Total 17 Units

The final year is split about 50.50 between forestry, with special emphasis on lumbering and products, and chemistry. The courses are as follows:-

\author{
Forest History \\ General Logging \\ Milling and Marketing \\ Forest Products \\ Forest Economics \\ Chemical Engineering \\ Advanced Organic Chemistry \\ Physical Chemistry
}

\section{Total 18 Units}

The forest business administration option is designed to equip men who are interested in entering the business end of the forest industries rather than Government service or research. Through co-operation with the Department of Commerce of the University we are able to offer the students five courses in their department in addition to the basic forestry courses. Their program for the last two years is as follows:-

Third Year

Silviculture

Mensuration

Forest Management

Wood Technology

Forest History

Accounting

Seminar

Total 17 Units.

Fourth Year

Lumber Grading

General Logging

Milling and Marketing

Forest Products

Forest Economics

Seminar

Commercial Law

Marketing

Business Finance

Industrial Management

Total 23 Units 


\section{Forest Engineering}

The Forest Engineering option leading to the degree of B.A.Sc. differs from the above in that students wishing to follow this branch are required to take physics instead of biology in first year Arts and Science; and that throughout the first two years of Applied Science the emphasis is on physics, mathematics and civil engineering rather than on the biological sciences. The course taken by forest engineering students during these two years is the same as that taken by all engineering students except that courses in forest botany, general forestry, and silvics are substituted for quantitative and qualitative chemical analysis.

In the third year the forest engineering course is as follows:-

Hydraulics

Elementary Design

Strength of Materials

Material Testing

Mapping

Silviculture

Mensuration

Forest Surveying and Mapping

Wood Technology

Forest Fire Protection

Dendrology

Total 22 Units

In the fourth year the course consists of the following subjects:-

Forest Pathology
Forest Entomology
Wood Technology
Forest History
General Logging
Logging Engineering
Milling and Marketing
Lumber Grading
Forest Products
Forest Management
Seminar

The above option is designed to train men for the production and engineering phases of the forest industries and is essentially the same course today as that offered by the Department of Forestry ever since its inception. The greater percentage of our graduates up to the present have been forest engineers, and they have proven to be excellent men and a credit to the University.

From the foregoing it may be seen that all students, no matter which option they follow, get about the same basic training in forestry, with an opportunity for specialization in one of four separate fields. The following chart summarizes the courses given in each of the four options, on the basis of units required for graduation. 


Sobjects
Forestry $\ldots \ldots \ldots \ldots$
Botany and Biology
Engineering $\ldots \ldots \ldots$
Chemistry $\ldots \ldots \ldots$
Physics $\ldots \ldots \ldots$
Economics and
Commerce $\ldots \ldots \ldots$
English $\ldots \ldots \ldots \ldots$
Others $\ldots \ldots \ldots \ldots$

Total ..........

\begin{tabular}{|c|}
\hline $\begin{array}{c}\text { Technical } \\
\text { Forestry } \\
\text { (No. of Units) } \\
36\end{array}$ \\
\hline 19 \\
\hline 4 \\
\hline 6 \\
\hline 3 \\
\hline 3 \\
\hline 5 \\
\hline 3 \\
\hline 85 \\
\hline
\end{tabular}

Forest Engineering
(No. of Units)

34

34

7 .

27

3

10

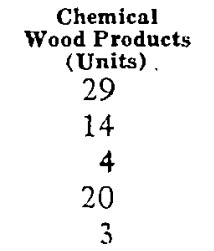

F.B.A.;

31

14

4

6

3

-
6
107

3

5

3

87

18

5

6

93

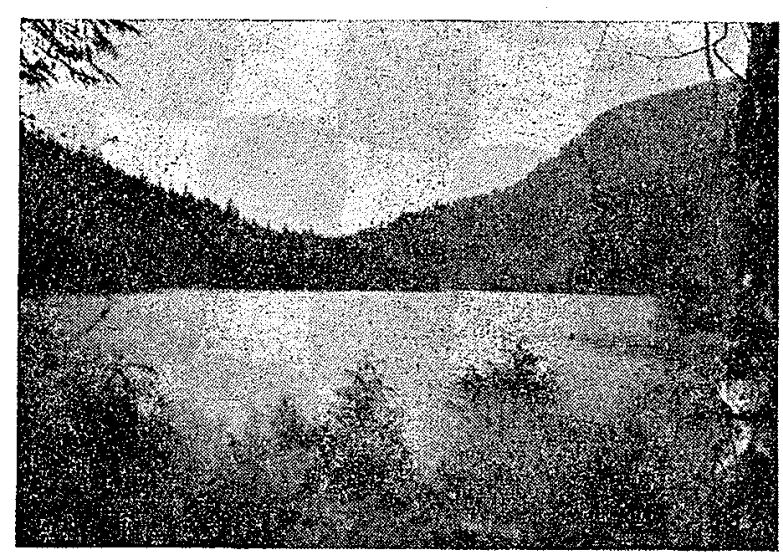

Loon Lake. Proposed permanent camp, University Forest Reserve.

\section{UnIVERSITY Forest Reserve}

In addition to formal study during the University sessions each student is required to have at least two seasons summer employment in some phase of forestry or the forest industries before graduation. Also the second and third year classes are required to spend four weeks at the University Forest Reserve at Haney during the month of May. During this time the students are given intensive field work in surveying, mapping, mensuration and re. search; and have the opportunity of applying in the field the knowledge gained in the classroom.

The University Forest Reserve consists of 10,000 acres of forest land near Haney in the Fraser Valley. It can be reached by auto from the campus in about 2 hours over a good road. We are fortunate in that the reserve contains most species found in British Columbia and a multiplicity of conditions and sites, ranging from recently logged and burned areas, through a. succession of age classes. There is about 40 million feet of mature timber in the reserve. As the gathering of basic information is completed it is planned 
to place the area on a sustained yield basis, and to conduct experiments in planting, seeding, thinning, pruning, logging and milling right on the property.

The staff of the Department consists of 2 professors, 4 associate professors, 1 assistant professor and 2 part-time lecturers.

\section{Post-Graduate Courses}

The University at present does not offer any post-graduate courses in forestry. Our main concern is to get the undergraduate courses working smoothly and to take care of our tremendously increased enrolment in the undergraduate courses. In a couple of years' time, however, when these difficulties are eliminated, we expect to offer post-graduate courses leading to a master's degree, and to build up our staff by the addition of at least two more men.

\section{SPRCIALIZEd COURSES IN FORESTRY}

While we have four options open for forestry students at the present time which allow for a certain amount of specialization, and while we realize that there is a need and a place for some degree of specialization, we feel that in undergraduate work especially this can sometimes be carried too far. It is our belief that undergraduates should receive a comprehensive training in all phases of their chosen profession and any high degree of specialization should be undertaken through post-graduate work.

\section{Present Enrolment in Forestry}

The present enrolment in Forestry is about 330. Like all other Universities throughout Canada and the United States we have experienced a tremendous influx of students during the past 2 years. In the session 1943-44 there were 41 students in forestry. The outstanding fact regarding enrolment is that, while the total for the University has increased about 300 per cent in the last two years, that in forestry has increased about 800 per cent. This tremendous increase in forestry enrolment compared with the total enrolment in British Columbia may be attributed to two factors: the interest aroused in forestry throughout the Province by the recent inquiry of the Royal Commission on Forestry, and the large influx of forestry students from the Prairie Provinces where no forestry courses are available.

\section{OPPORTUNITIES FOR EMPLOYMENT}

The prospect for employment of such a large number of graduates two or three years hence is one which all Forest Schools should be thinking about now. For my part, I cannot feel pessimistic. I think that in British Columbia the demand for these graduates will be great enough to absorb the vast majority. It is impossible, of course, to predict with any degree of accuracy the economic conditions one year in advance, let alone three or four, in our fast moving modern world. But I feel that with the present and potential demand of the Government Services in British Columbia and the Prairie Provinces, together with the expanding demand of the forest industries for trained foresters and logging engineers, the prospects for the graduate forester in the near future are as bright as in any other profession. 


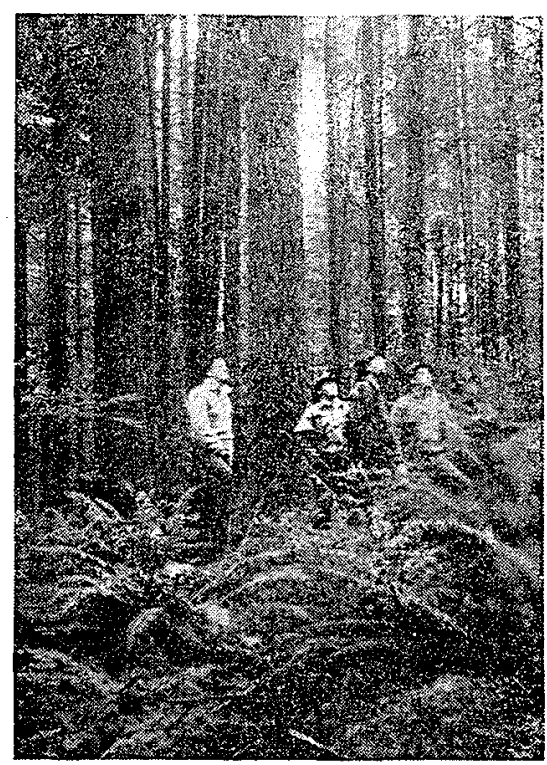

Silviculture class in 87 year old Douglas Fir. University Forest Reserve.

\section{Employment of Graduates to Date}

$U_{p}$ to the present time the Department has graduated 101 men. Of these 85 per cent are directly employed in one phase or other of Forestry. Some are teaching in Universities, many have qualified for their doctorate at other universities. The largest percentage are employed by private industry as foresters, logging engineers, or executives in British Columbia. Some few have found employment with the Dominion Government, while a small percentage have gone to the United States or Eastern Canada and are there employed with industry.

Throughout the life of the Department of Forestry at the University of B.C. we have tried to satisfy the requirements of both industry and Government as to the type of man they are looking for. The record of our graduates in the past speaks for itself. I have every confidence that the graduates of the future will maintain this record. 